\title{
Estimating the grazing pressure of heterotrophic nanoplankton on Synechococcus spp. using the sea water dilution and selective inhibitor techniques*
}

\author{
Lisa Campbell ${ }^{* *} \&$ Edward J. Carpenter \\ Marine Sciences Research Center, State University of New York, Stony Brook, New York 11794, USA
}

\begin{abstract}
Marine, phycoerythrin-containing Synechococcus spp. are now recognized as a major component of the photosynthetic biomass in oceanic waters. Although these picoplankters potentially are important food sources for heterotrophic nanoplankton, the cycling of Synechococcus biomass has not yet been well described. Two approaches recently proposed for measuring grazing pressure by heterotrophic nanoplankton (2 to $20 \mu \mathrm{m}$ ) were used to measure specific grazing rates on Synechococcus spp.: (1) the sea water dilution culture technique of Landry \& Hassett (Mar. Biol. 67: 283-288); (2) the selective inhibitor method of Fuhrman \& McManus (Science 224: 1257-1260). Several samples were collected at coastal and oceanic Northwest Atlantic sites and grazing estimates by the 2 methods were compared. Grazing coefficients, $g\left(\mathrm{~d}^{-1}\right)$, ranged from 0 to $0.35 \mathrm{~d}^{-1}$ at an oceanic warm core eddy (WCE) station, but were greater (up to $0.83 \mathrm{~d}^{-1}$ ) at the coastal stations. At the coastal station, both methods yielded similar rates, but at the WCE station, where Synechococcus spp. abundance was low, only the selective inhibitor produced significant grazing estimates. Sample dilution may have reduced cell numbers below a grazing threshold. In such cases, the inhibitor method may provide more reliable measurements. Using the grazing coefficients from these experiments, consumption of Synechococcus biomass was compared with production by Synechococcus populations. At the WCE and Long lsland Sound stations, 37 to $52 \%$ of the Synechococcus biomass produced was consumed by grazers, whereas at the coastal Gulf of Maine station the biomass produced appeared to be balanced by the biomass consumed.
\end{abstract}

\section{INTRODUCTION}

Small photosynthetic picoplankters such as Synechococcus spp. are well recognized as major components of biomass in warm oceanic waters of the Atlantic and Pacific oceans (Platt et al. 1983, Takahashi \& Bienfang 1983, Takahashi \& Hori 1984, Glover et al. 1986). As the importance of the picoplankton, as well as the nanoplankton (Malone 1971) and the bacteria (Williams 1981), to the plankton community has been recognized, it has been necessary to revise the traditional paradigm of a netplankton-copepodfish pelagic food chain (Azam et al. 1983). Each of these additional components contributes to a complex food web (Pomeroy 1974), which is characteristic of both oceanic and coastal regions (Sieburth \& Davis

\footnotetext{
- Marine Sciences Research Center Contribution No. 526

- Present address: Dept. of Oceanography, University of Hawaii at Manoa, Honolulu, Hawaii 96822, USA

1982). Many investigators now envision the oceanic food web as a highly dynamic and balanced system (Goldman et al. 1979, Azam et al. 1983). Synechococcus spp. generally are the numerically dominant picoplankters ( $\mathrm{Li}$ et al. 1983, Glover et al. 1986); the cycling of Synechococcus biomass is therefore of importance to our understanding of the pelagic food web.

Heterotrophic nanoplankters, which include the aplastidic flagellates and aloricate ciliates of $<20 \mu \mathrm{m}$ diameter (Sherr et al. 1986), are often assumed to be the primary grazers of Synechococcus spp., but there is little experimental evidence to support this assumption. Previously, one Synechococcus sp. (clone not designated) was found to be non-nutritious for Fabrea salina, a large euryhaline ciliate (Repak 1983), but cultures of the tiny ciliate Uronema sp. and the microflagellate Actinomonas sp. have been maintained on phycoerythrin-containing Synechococcus strains (Johnson et al. 1982). Uronema grazed preferentially 
on the cyanobacteria over heterotrophic bacteria (Johnson et al. 1982). In field samples from Georges Bank, where Synechococcus spp. are abundant, these cyanobacteria were observed in phagotrophic flagellates as intact and as partially digested cells within vacuoles (Johnson et al. 1982). Other observations of field samples showed that ciliates contained cyanobacteria, which were recognizable by their autofluorescence (McManus pers. comm.). Perkins et al. (1981) also observed cyanobacteria within food vacuoles of heterotrophic flagellates. None of these studies have documented rates of grazing on Synechococcus populations.

Since cyanobacterial numbers are 10 times those of the heterotrophic nanoplankton, Sieburth \& Davis (1982) postulated that cyanobacteria are abundant enough to be considered an adequate food supply for heterotrophic nanoplankton. Furthermore, the growth rates of heterotrophic nanoplankton have been estimated to be 1 to 2 divisions $d^{-1}$ (Kopylov \& Moiseev 1980, Sherr \& Sherr 1983) which is within the same time scale as growth rates of the picoplankton (Bienfang \& Takahashi 1983) and, in particular, Synechococcus (Waterbury 1984, Campbell \& Carpenter 1986). By comparing estimates of Synechococcus growth rates with estimates of grazing rates, the cycling of Synechococcus biomass can be investigated.

The objective of this work was to estimate grazing rates of Synechococcus spp. by the heterotrophic nanoplankton. Two approaches have been used recently to measure grazing on bacteria in aquatic environments: (1) sample dilution to reduce grazing pressure, and (2) the use of metabolic inhibitors to selectively inhibit growth of the bacterium and allow direct measurement of grazing. The first technique was proposed by Landry \& Hasset (1982) to estimate grazing pressure on phytoplankton communities and has been used recently to estimate the population growth coefficient, $k$, and population grazing mortality coefficient, $g$, for cyanobacteria off Hawaii (Landry et al. 1984). In this method it is assumed that cell growth is exponential, that the rate of population increase is limited by grazers, provided nutrients are not exhausted, and that consumer grazing rates are independent of prey concentration. When the sample is diluted with cell-free water, thereby reducing the grazer density, the net rate of growth should increase proportionally. Indirectly, then, the grazing coefficient can be calculated.

The use of metabolic inhibitors to estimate bacterial grazing rates was proposed by Newell et al. (1983), and a modification of this method was used recently by Fuhrman \& McManus (1984) for estimating bacterial grazing rates in Long Island Sound. In a sample where the Synechococcus population is held at a constant level using ampicillin (an inhibitor of prokaryotic cell division that is assumed not to affect eukaryotic organisms), the number of cells remaining is monitored over time. As a control, both ampicillin and cycloheximide (a specific inhibitor of protein synthesis in eukaryotic cells; Watanabe 1972) are used to confirm that the number of cyanobacteria remains constant in the absence of grazing by heterotrophic nanoplankton. Using these 2 methods, estimates of grazing were made at several coastal and oceanic stations to determine the specific grazing rates on Synechococcus spp.

\section{MATERIALS AND METHODS}

Field experiments. Grazing experiments were conducted in July and August 1984 in the Northwest Atlantic Ocean on the R/V Cape Hatteras at 2 stations: P1, a neritic frontal station $\left(43^{\circ} 27^{\prime} \mathrm{N}, 68^{\circ} 36^{\prime} \mathrm{W}\right)$ in the Gulf of Maine; and P2, a warm core eddy (WCE) station $\left(39^{\circ} 31^{\prime} \mathrm{N}, 66^{\circ} 20^{\prime} \mathrm{W}\right)$, which was assumed to be similar to Sargasso Sea water (C. S. Yentsch pers. comm.). Two experiments were run at each station with samples from the depth of maximum Synechococcus abundance: surface at Stn P1 and at, or just above, the chlorophyll a maximum at Stn P2. One additional experiment was performed at a Long Island Sound (LIS) site with a sample collected from Stony Brook Harbor in August 1984.

Samples were collected with acid-cleaned (1.2 N $\mathrm{HCl}$ ) Go-Flo bottles (General Oceanics). To calculate both $g$ and $k$, each sample was given 5 different treatments: no alteration; dilution with cell-free sample water in $1: 1$ and $1: 4$ ratios (sample: cell-free water); ampicillin addition (5 $\mathrm{mg} \mathrm{l}^{-1}$; Sigma); and ampicillin with cycloheximide $\left(100 \mathrm{mg} \mathrm{l}^{-1}\right.$; Sigma) as a control. Cell-free water was obtained by filtering the sample water first through a $3 \mu \mathrm{m}$ Nuclepore filter (by gravity) followed by filtration through a disposable sterile $0.2 \mu \mathrm{m}$ Corning filter assembly

For each treatment, $750 \mathrm{ml}$ volumes in Whirlpak bags were incubated in on-deck incubators cooled with running surface sea water and screened to simulate the light intensity at depth of collection, or not screened for surface light intensity. Incubations began at dawn (except on July 22 , when the experiment was begun at $2200 \mathrm{~h}$ ) and continued for 18 to $24 \mathrm{~h}$ (with the exception of the $12 \mathrm{~h}$ experiment on July 24).

Duplicate $50 \mathrm{ml}$ subsamples were taken at $6 \mathrm{~h}$ intervals, preserved with $5 \%$ buffered formalin, and refrigerated and protected from light until counted (within $2 \mathrm{wk}$ ). Samples were filtered onto stained ( $2 \%$ Irgalan Black) $0.4 \mu \mathrm{m}$ Nuclepore filters and 200 to 400 cells per filter were counted. Growth rates were also calculated by the frequency of dividing cells technique (FDC) at Stns P1 and P2. FDC counts used for calculating 
growth rates were made at the same time replicates were counted for dilution experiments. In situ productivity measurements were made from dawn-to-dusk incubations (see Glover et al. 1986).

Laboratory control experiments. Using the pure culture WH7803, control experiments were conducted in which growth was monitored in the presence of ampicillin ( $5 \mathrm{mg}$ and $10 \mathrm{mg} \mathrm{l}^{-1}$ ) or cycloheximide $\left(100 \mathrm{mg} \mathrm{^{-1 } )}\right.$ to verify that ampicillin prevented cell division without causing cell lysis, and to verify that cycloheximide did not adversely affect growth of the cyanobacteria.

Calculations. To calculate growth rates of Synechococcus spp., growth was assumed to be exponential such that population density at a given time $\left(N_{t}\right)$ can be represented by:

$$
N_{t}=N_{0} e^{r t}
$$

The rate of growth is given by first order kinetics:

$$
\mathrm{dN} / \mathrm{dt}=\mathrm{rN}
$$

where $r=$ the observed rate of increase and is a balance between growth, $\mathrm{k}$, and mortality due to grazing, g. Therefore:

$$
\mathrm{I}=\mathrm{k}-\mathrm{g}=\frac{\mathrm{l}}{\mathrm{t}} \ln \frac{N_{\mathrm{t}}}{\mathrm{N}_{\mathrm{o}}}
$$

In the dilution method proposed by Landry \& Hasset (1982), it is assumed that the exponential cell growth is not altered by sample dilution and that the rate of population increase is limited by grazers. Furthermore, it must be assumed that grazing rate is constant, and is not saturated by natural prey densities. Under these conditions, the rate of increase, $r$, is the difference between the instantaneous growth coefficient $(\mathrm{k})$ and the grazing mortality coefficient ( $g$ ). The instantaneous growth equation (Eqn 3) was used to calculate $I$ for each of the dilution treatments using $N$ at the dawn time point for $\mathrm{N}_{0}$ and at the end point for $\mathrm{N}_{\mathrm{l}}$. To obtain a daily rate, $\mathrm{r}\left(\mathrm{h}^{-1}\right)$, was multiplied by $24 \mathrm{~h}$. Long incubation times ( 18 to 24 h) were used so that measurable increases in cell numbers could be counted and to avoid errors owing to the diel pattern in cell division. Time-course experiments showed a lag-phase for cell number increase, but this apparent lag was the result of phased cell division, such that the maximal number of cells divided after sunset (Campbell \& Carpenter 1986). Consequently, the number of cells increased exponentially at the end of the light period. Calculating a growth rate from a regression of this portion of the curve would be an overestimate; therefore, the instantaneous growth equation, which gives a more appropriate average, was used.
Since the dilution method is based on the assumption that $\mathrm{g}$ is proportional to the grazer density (and therefore proportional to the fraction of undiluted sample, \% g), $g$ and $k$ were estimated from regressions of $r$ vs $\% g$. The value of $\mathrm{k}$ is the $\mathrm{y}$-intercept (when $\% \mathrm{~g}=0$ ) and $\mathrm{g}$ is the slope of the regression line (see Landry \& Hassett 1982, Landry et al. 1984). The significance of regression lines was tested by a t-test with the null hypothesis of $\mathrm{g}=0$ (Sokal \& RohIf 1969).

By the selective inhibitor method, independent estimates of $g$ were calculated from the rate of disappearance of cells (Eqn 3) in the ampicillin treatments, minus the control. The grazing rate was assumed to be constant over the course of the experiment, so that $\mathrm{g}\left(\mathrm{h}^{-1}\right) \times 24=$ daily grazing coefficient.

In situ ${ }^{14} \mathrm{C}$-production data was available for the Northwest Atlantic stations (Glover et al. 1986); thus, production estimates calculated for Synechococcus spp. populations using the measured growth coefficients obtained in this study could be compared with the in situ data. Production and consumption of Synechococcus biomass were calculated assuming a carbon value of $294 \mathrm{fg} \mathrm{C} \mathrm{Cell}^{-1}$ (Cuhel \& Waterbury 1984):

$$
\begin{gathered}
\text { Production }=\mathrm{k} \mathrm{N}_{0} \mathrm{C} \mathrm{cell}^{-1} \quad\left(\mu \mathrm{gCl}^{-1} \mathrm{~d}^{-1}\right) \\
\text { Consumption }=\mathrm{g} \mathrm{N}_{\circ} \mathrm{C} \mathrm{cell}^{-1} \quad\left(\mu \mathrm{gC}^{-1} \mathrm{~d}^{-1}\right)
\end{gathered}
$$

\section{RESULTS}

\section{Laboratory experiments}

Preliminary control experiments with Synechococcus strain WH7803 indicated that ampicillin $15 \mathrm{mg}$ $1^{-1}$ ) prevents cell division (Fig. 1) and does not cause

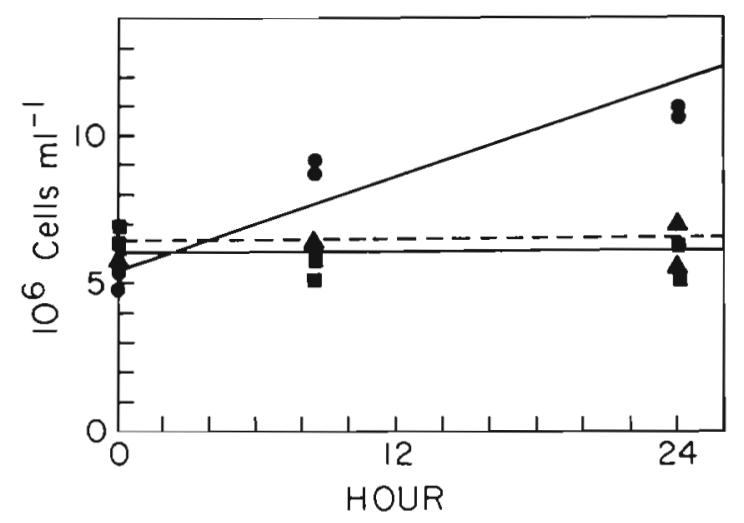

Fig. 1. Synechococcus strain WH7803. Control experiment to determine effect of ampicillin ( 5 and $10 \mathrm{mg} \mathrm{l}^{-1}$ ) on cell division. Regression slopes are significantly different when tested by the t-test (Sokal \& Rohlf 1969), p $<0.001$. C) Control; (一-U) $5 \mathrm{mg} \mathrm{l}^{-1} ;(\mathbf{L} \ldots \mathbf{A}) 10 \mathrm{mg} \mathrm{l}^{-1}$ 


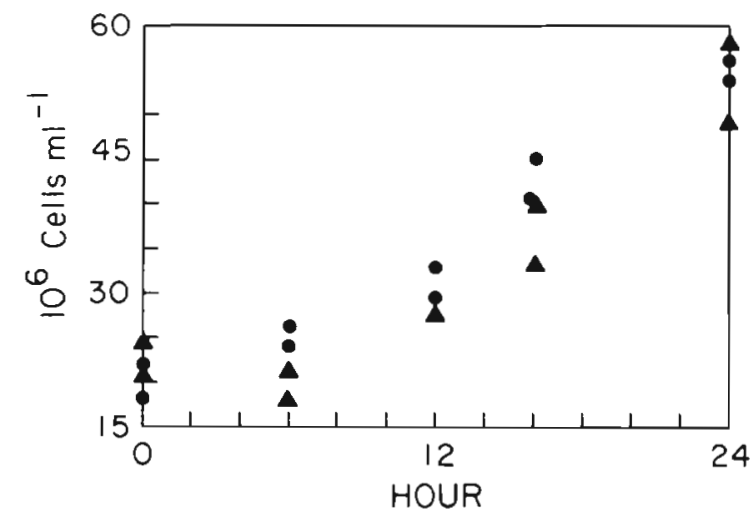

Fig. 2. Synechococcus strain WH7803. Growth was not inhibited by the presence of cycloheximide $\left(100 \mathrm{mg} \mathrm{l}^{-1}\right)$ and was not significantly different from growth under control conditions $(p>0.05)$. ( $\bullet$ Control; ( $\Delta$ ) cycloheximide

cells to lyse, while cycloheximide $\left(100 \mathrm{mg} \mathrm{l}^{-1}\right)$ has no significant effect on cell division (Fig. 2; p>0.05; F-test, Sokal \& Rohlf 1969).

\section{Sea water dilution grazing experiments}

In the dilution method experiments, net growth in the diluted samples was significantly greater than net growth in the untreated samples at both the neritic frontal (P1) and the Long Island Sound (LIS) stations (Fig. $3 a, b, c)$. Regressions of the data were significant for experiments at Stns P1 $(p<0.05)$ and LIS $(p<0.01)$. The observed grazing mortality coefficients ranged from 0.22 to $0.83 \mathrm{~d}^{-1}$ (Table 1), but $g$ was several times lower at the LIS station than at Stn P1 (Table 1). At the WCE station, P2, the regression coefficient for the July 26 experiment was not significantly different from zero (Fig. 3b). Also, growth was not observed in either diluted treatments in the July 29 experiment. Consequently, grazing mortality coefficients could not be calculated by the dilution method at Stn P2.

\section{Selective inhibitor experiments}

Specific grazing rates in the ampicillin treatment were significantly different from the ampicillin-pluscycloheximide control ( $p<0.001$; Mann-Whitney Test; Sokal \& Rohlf 1969) (Fig. 4 a to d). The specific grazing rates at Stn P1 $\left(0.61\right.$ to $\left.0.79 \mathrm{~d}^{-1}\right)$ were about twice the rates at Stn P2 (0.33 to $0.35 \mathrm{~d}^{-1}$ ) (Table 1).

Overall, estimates of $\mathrm{g}$ by the 2 methods were in close agreement at the coastal station, but were not comparable at the WCE station, P2, where the lower grazing rates were not measurable by the dilution technique.
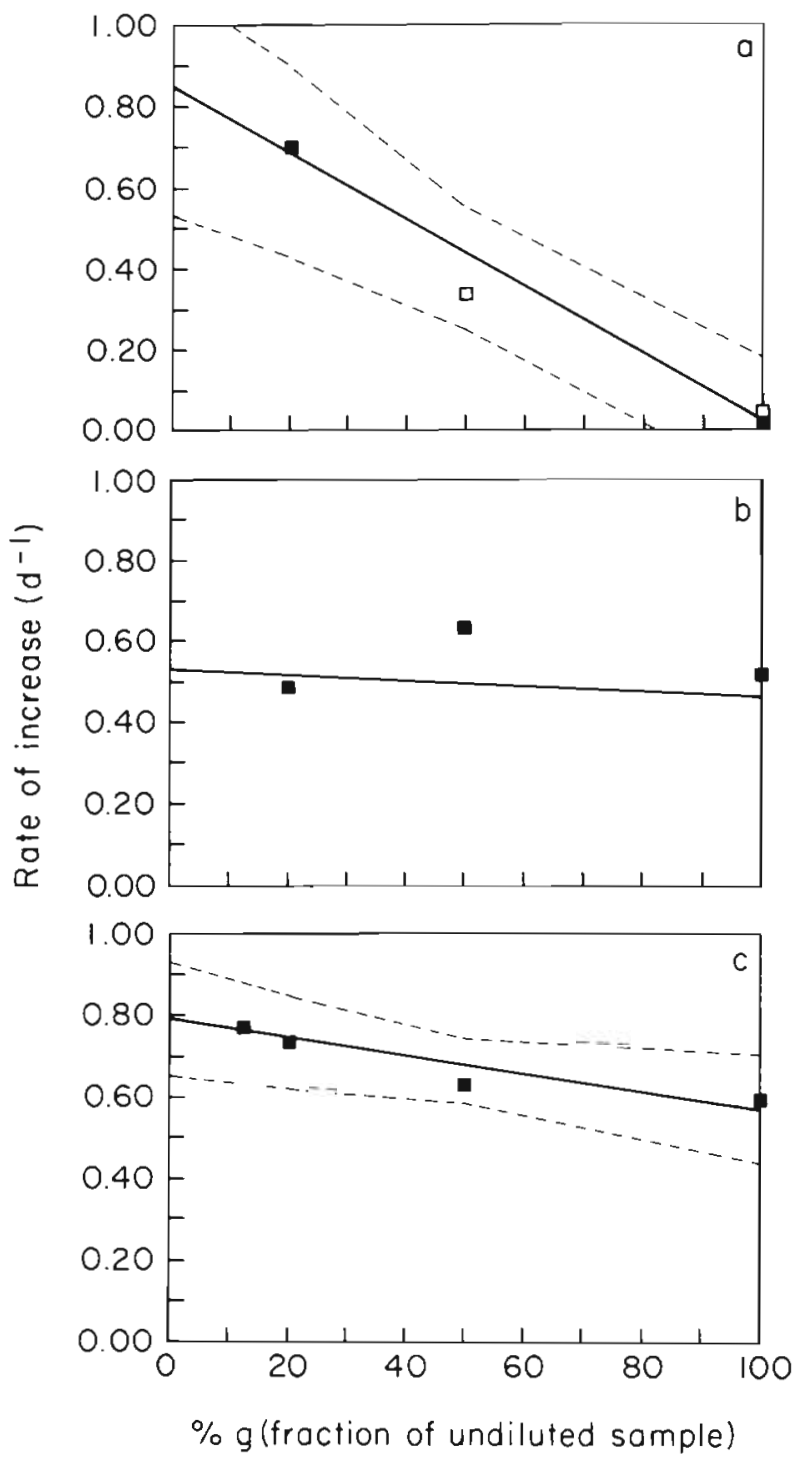

Fig. 3. Grazing experiments using dilution method of Landry \& Hassett (1982) to estimate the instantaneous growth coefficient, $\mathrm{k}\left(\mathrm{d}^{-1}\right)$, and grazing mortality coefficient $\mathrm{g}\left(\mathrm{d}^{-1}\right) .95 \%$ confidence limits about each regression line are shown. (a) Neritic coastal station (P1) in the Northwest Atlantic. Data from ( $\square$ ) 22 and (ロ) 24 Jul 1984 were pooled because 1 dilution was lost from each experiment. (b) Warm core eddy station, (P2), $26 \mathrm{Jul}$ 1984. Regression slope not significantly different from 0 (p>0.05). (c) Long Island Sound station, 29 Aug 1984. Regression slope significant at $p<0.01$

\section{Growth coefficient and production estimates}

In comparing the growth coefficients, $k\left(d^{-1}\right)$, obtained from the dilution experiments (Fig. $3 \mathrm{a}$ to $\mathrm{c}$ ) with the specific growth rates calculated from frequency of dividing cells (FDC) data (Table 1), the estimates were similar, and at the WCE station, P2, the estimates in each experiment were in close agreement. Production and consumption estimates show that 37 to $52 \%$ of the Synechococcus production appears to be 
Table 1. Comparison of daily instantaneous growth $(k)$ and grazing mortality $(g)$ coefficients ( $\pm S E ; n=$ number of samples) for phycoerythrin-containing Synechococcus populations from 3 stations in the North Atlantic: a coastal station (P1); within a warm core eddy (P2); and in Long Island Sound (LIS). Calculations by dilution method of Landry \& Hassett (1982) and selectiveinhibitor method of Fuhrman \& McManus (1984) for samples incubated at $25^{\circ} \mathrm{C}$

\begin{tabular}{|c|c|c|c|c|c|c|}
\hline \multirow[t]{2}{*}{$\begin{array}{l}\text { Date } \\
(1984)\end{array}$} & \multirow[t]{2}{*}{ Station } & \multirow[t]{2}{*}{$\begin{array}{l}\text { Sample depth } \\
\text { (m) }\end{array}$} & \multicolumn{2}{|c|}{$\begin{array}{l}\text { Growth coefficients } \\
\qquad \mathrm{k}\left(\mathrm{d}^{-1}\right)\end{array}$} & \multicolumn{2}{|c|}{$\begin{array}{l}\text { Grazing coefficients } \\
\mathrm{g}\left(\mathrm{d}^{-1}\right)\end{array}$} \\
\hline & & & Dilution & $\mathrm{FDC}^{\mathrm{a}}$ & Dilution & Inhibitor ${ }^{b}$ \\
\hline $22 \mathrm{Jul}$ & $P 1^{r}$ & Surface & $\begin{array}{c}0.84 \pm 0.05^{\circ} \\
\mathrm{n}=4\end{array}$ & 0.54 & $\begin{array}{c}0.83 \pm 0.09 \\
n=4\end{array}$ & $0.79 \pm 0.02$ \\
\hline $24 \mathrm{Jul}$ & P1 & Surface & & 0.59 & & $0.61 \pm 0.12$ \\
\hline $26 \mathrm{Jul}$ & $\mathrm{P} 2$ & 30 & $\begin{array}{l}0.52 \pm 0.12^{\mathrm{ns}} \\
\mathrm{n}=3\end{array}$ & 0.63 & $\begin{array}{c}0.06 \pm 0.12^{\mathrm{ns}} \\
\mathrm{n}=3\end{array}$ & $0.33 \pm 0.04$ \\
\hline $29 \mathrm{Jul}$ & $\mathrm{P} 2^{\mathrm{d}}$ & 36 & $0.94 \pm 0.13$ & 0.86 & 0 & $0.35 \pm 0.09$ \\
\hline 29 Aug & LIS & Surface & $\begin{array}{c}0.78 \pm 0.03 \cdots \\
n=4\end{array}$ & - & $\begin{array}{c}0.22 \pm 0.06 \cdots \\
n=4\end{array}$ & -. \\
\hline \multicolumn{7}{|c|}{$\begin{array}{l}{ }^{2} \text { FDC estimate of growth rate by frequency of dividing cells technique (Campbell \& Carpenter 1986); SE not available } \\
\text { b } \pm \text { range of duplicates } \\
{ }^{c} \text { Data from } 2 \text { dilution experiments ( } 22 \text { and } 24 \text { Jul) were pooled to test the significance of the regression line } \\
\text { d Calculated from undiluted sample; no growth observed in diluted treatments } \\
\text { - } p<0.05 ; \cdots p<0.01{ }^{\text {ns }} \text { not significantly different from } 0 ;-- \text { not measured }\end{array}$} \\
\hline
\end{tabular}
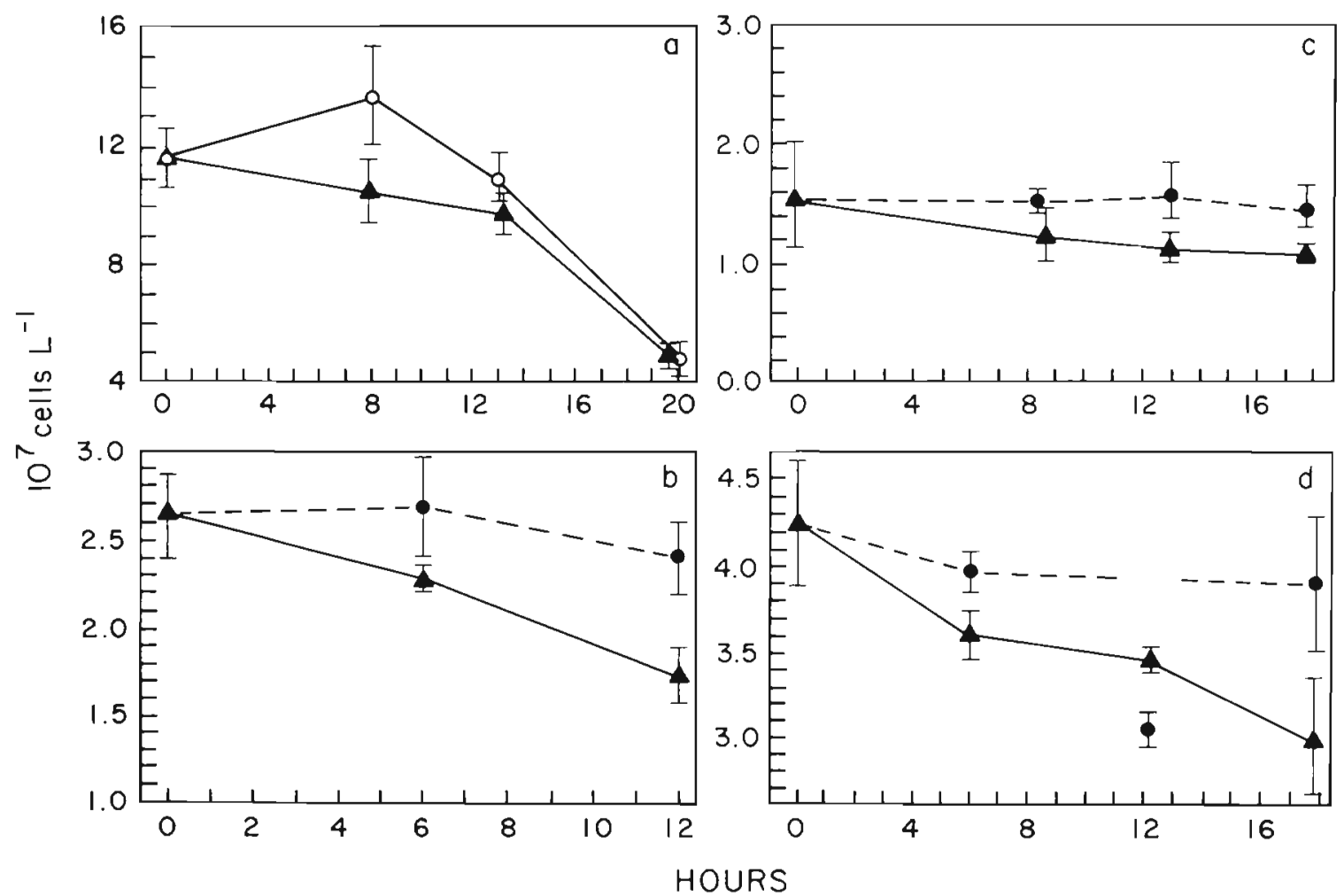

Fig. 4. Grazing experiments using the selective prokaryote-inhibitor technique of Fuhrman \& McManus (1984). In grazed treatment ampicillin prevented cell division of Synechococcus; thus, rate of cell disappearance (owing to grazing by heterotrophic nanoplankton) was measured directly. When both ampicillin and cycloheximide (an inhibitor of eukaryotic cells) were added as a control, disappearance of cells was reduced or prevented. Range of duplicate counts is given. (a) Neritic frontal station

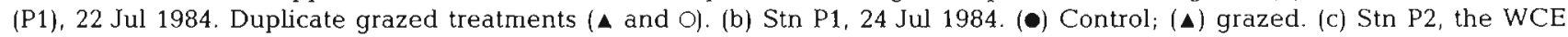
station, 26 Jul 1984. Symbols as in (b). (d) Stn P2, 29 Jul 1984. Symbols as in (b) 
consumed by grazers at the WCE and LIS stations, whereas at Stn P1, the amount of biomass produced is balanced by the amount consumed by grazing (Table 2).

Data from in situ ${ }^{14} \mathrm{C}$-productivity experiments were available for the same depths that samples were collected for the grazing experiments (Glover et al. 1986). Each ${ }^{14} \mathrm{C}$-production value in Table 2 is the production contributed by the Synechococcus spp. population calculated from size-fractionated dawn-to-dusk productivity experiments. The production estimates calculated using growth coefficients obtained from both the sea water dilution experiments and the frequency of dividing cell experiments were consistently higher than the ${ }^{14} \mathrm{C}$-production estimates. At Stn P1, where the greatest discrepancy between production estimates occurred (5 to 28 times higher than the ${ }^{14} \mathrm{C}$ production), the highest grazing mortality coefficients were measured (Table 1). At the WCE station, production estimates were closer, (although the estimates by both our experimental methods did exceed the ${ }^{14} \mathrm{C}$-production estimate by several times), but grazing coefficients were half those measured at P1 (Table 1).

\section{DISCUSSION}

The goal of our research was to determine the grazing pressure on Synechococcus spp. populations by heterotrophic nanoplankton. Using 2 different approaches, the dilution method of Landry \& Hassett (1982) and the prokaryote-inhibitor method of Fuhrman \& McManus (1984), the grazing mortality coefficients measured were not significantly different at Stn P1. At the WCE station, P2, however, only the selective inhibitor method produced a statistically significantly grazing rate. It is possible that the dilution of samples at Stn P2 brought Synechococcus abundance below a grazing threshold. Landry et al. (1984) predicted a grazing threshold of $60 \times 10^{6}$ cells $1^{-1}$, and, in fact. Synechococcus spp. densities at Stn P2 were at or below this concentration. Thus, our preliminary study suggests that the ampicillin inhibitor method may produce more reliable results than the dilution technique, especially at low cell concentrations, where dilution would only further decrease cell abundance. Also, the inhibitor method requires fewer sample manipulations than the dilution technique, so the sample is less likely to be affected by changes introduced by filtration le.g. altered nutrient conditions brought about by release of dissolved amino acids during filtration; Fuhrman \& Bell 1985). The effect of nutrient limitation on cyanobacteria can also bias the observed growth rates in some sample dilutions so that the grazing rate is overestimated, as was shown by Landry \& Hassett (1982). Subsequently, Landry and his co-workers have used dialysis bag incubation chambers to approximate natural nutrient conditions (Landry et al. 1984). It is unlikely that $g$ was overestimated in our experiments at the oligotrophic station where nutrients were low (Glover et al. 1986), but such an error is possible for the coastal samples. The effect of nutrient limitation is an important consideration when conducting dilution experiments.

The application of the specific-inhibitor method depends on both the effectiveness and specificity of the inhibitor. In our application, ampicillin appears to meet both criteria: it inhibits cell division of Synechococcus (Fig. 1) and does not affect the growth of selected heterotrophic nanoplankton (authors' unpubl. data). The grazing rate was not constant in all experiments, thus the time and duration of incubations will affect the estimate. Experiments to investigate the diel variation in the grazing rate are currently underway.

The estimates of grazing mortality coefficients, $g$, for

Table 2. Synechococcus spp. Production estimates for populations at 2 stations in the Northwest Atlantic: a comparision of estimated carbon production and consumption with measured rates of ${ }^{14} \mathrm{C}$-production. Production calculated from Eqn (4) and consumption calculated from Eqn (5). ${ }^{14} \mathrm{C}$ production rates for corresponding sample depths were from dawn-to-dusk in situ incubation experiments that were size-fractionated so that the contribution by Synechococcus spp. could be calculated (from Glover et al. 1986)

\begin{tabular}{|c|c|c|c|c|c|c|c|c|}
\hline \multirow[t]{2}{*}{ Station } & \multirow{2}{*}{$\begin{array}{l}\text { Date } \\
\text { (1984) }\end{array}$} & \multirow{2}{*}{$\begin{array}{l}\text { Sample } \\
\text { depth } \\
\text { (m) }\end{array}$} & \multirow{2}{*}{$\begin{array}{l}\text { Initial cell } \\
\text { count } \\
\left(10^{6} \mathrm{l}^{-1}\right)\end{array}$} & \multicolumn{2}{|c|}{$\begin{array}{l}\text { Production } \\
\left(\mu g \mathrm{C}^{-1} \mathrm{~d}^{-1}\right)\end{array}$} & \multicolumn{2}{|c|}{$\begin{array}{l}\text { Consumption } \\
\left(\operatorname{lug} C \mathrm{l}^{-1} \mathrm{~d}^{-1}\right)\end{array}$} & \multirow{2}{*}{$\begin{array}{c}\text { In situ } \\
{ }^{14} \mathrm{C} \text {-production of } \\
\text { Synechococcus } \\
\left(\text { ug C }{ }^{-1} \mathrm{~d}^{-1}\right)\end{array}$} \\
\hline & & & & Dilution & FDC & Dilution & Inhibitor & \\
\hline P1 & $22 \mathrm{Jul}$ & 2 & 113.0 & $27.91 \pm 6 \%$ & 17.94 & $27.57 \pm 12 \%$ & $26.25 \pm 2 \%$ & \multirow{2}{*}{0.89} \\
\hline $\mathrm{P} 1$ & $24 \mathrm{Jul}$ & 2 & 27.0 & $6.67 \pm 6 \%$ & 4.68 & $6.59 \pm 12 \%$ & $4.84 \pm 20 \%$ & \\
\hline P2 & $26 \mathrm{Jul}$ & 30 & 16.4 & NS & 3.04 & NS & $1.59 \pm 12 \%$ & \multirow{2}{*}{1.19} \\
\hline $\mathrm{P} 2$ & $29 \mathrm{Jul}$ & 36 & 42.8 & $11.83 \pm 1 \%$ & 10.82 & NS & $4.40 \pm 26 \%$ & \\
\hline
\end{tabular}


Synechococcus spp. at an oceanic site (WCE) in our experiments ( 0 to $0.35 \mathrm{~d}^{-1}$ ) are similar to the values obtained by Landry et al. (1984) for waters off Hawaii $\left(0.14\right.$ to $\left.0.39 \mathrm{~d}^{-1}\right)$ and the recently reported results of Iturnaga \& Mitchell (1986) for the oligotrophic North Pacific $\left(0.2\right.$ to $\left.0.4 \mathrm{~d}^{-1}\right)$. The average population growth coefficient, $k,\left(0.77 \pm 0.19 \mathrm{~d}^{-1}\right)$ observed here for the Northwest Atlantic stations, however, is much lower than the estimates of $\mathrm{k}$ ( 1.6 to $\left.1.7 \mathrm{~d}^{-1}\right)$ by Landry et al. (1984) and Iturriaga \& Mitchell (1986). Variations in growth coefficients could be due to differences in strain types or to physical factors. In agreement with the 2 previous reports, the results of our study suggest that Synechococcus production exceeds the consumption by grazers at open ocean stations. In contrast, production is in close balance with consumption ( $g$ is approximately equal to $k_{i}$ Table 2 ) at the neritic station, P1. If the balance between production and consumption varies among oceanic regions, this may be of great significance to understanding the food chain dynamics and merits further study.

Unicellular cyanobacteria are a potential food source for both heterotrophic flagellates and ciliates in pelagic waters (Sieburth 1984). The importance of ciliates in the open sea is not certain because their numbers are so low in comparison with coastal areas (Fenchel 1982). In cultures, ciliates will grow with only cyanobacteria as a food source. The small marine ciliate Uronema for example is primarily benthic, but it and other ciliates are found in association with marine snow (Sieburth 1984, Caron et al. 1982). On these particles, bacterial numbers, including cyanobacteria, are enriched (Silver \& Alldredge 1981), so that ciliates, when present, would have an ample food supply. In contrast, heterotrophic flagellates are relatively abundant in pelagic waters. Sieburth \& Davis (1982) suggested that a close link exists between phagotrophic flagellates and the picoplankton. Heterotrophic flagellates can divide at approximately 1 to 2 divisions $\mathrm{d}^{-1}$ (Kopylov \& Moiseev 1980, Sherr \& Sherr 1983). As this rate is similar to the growth rates for many picoplankters, it is possible that there may be a constant grazing pressure on the picoplankton.

The potential importance of Synechococcus populations to the diet of flagellate and ciliate grazer populations may be quite significant. Of course, there are other possible grazers for cyanobacteria. Salps and other mucous net feeders can collect bacteria-sized particles. In experiments with ${ }^{3} \mathrm{H}$-thymidine labelled bacteria, Thalia democratica was shown to incorporate bacteria as well as ${ }^{14} \mathrm{C}$-labelled phytoplankton, although the uptake of phytoplankton was greater than the bacteria (Mullin 1983). Others have shown consumption of bacteria by salps (Harbison \& McAllister 1979), though at a much reduced efficiency compared to the consumption of larger particles. King et al. (1980) found bacteria to be a considerable percentage (25 to $50 \%$ ) of the daily diet of the larvacean Oikopleura dioica. On average, the larvaceans in their study ingested an amount of bacteria that was roughly half the larvacean population biomass. Such possible grazing losses were not accounted for or measured in our small volume experiments.

If heterotrophic nanoplankton are the important link between picoplankton and higher levels of the food chain, then these grazing data support the microbial loop proposed by Azam et al. (1983) and the importance of marine snow as aggregated food sources. The observation that the amount of Synechococcus biomass consumed is in close balance with the biomass produced suggests a steady-state system with fairly rapid cycling of biomass. Because food-chain efficiency depends on the predator:prey size ratio, heterotrophic nanoplankton are a necessary link between the bacteria and larger grazers (Fenchel 1984). This is true for the cyanobacteria as well. There is evidence that Synechococcus remain neatly packaged in copepod fecal pellets, apparently not digested by these larger zooplankters (Silver \& Alldredge 1981, Johnson et al. 1982, Azam pers. comm.). In contrast, they were found within food vacuoles of flagellates (Perkins et al. 1981), and appeared to be partially digested (Johnson et al. 1982)

Grazing on cyanobacteria and other picoplankters may be overlooked in standard productivity experiments, as well as in post-incubation size-fractioned ${ }^{14} \mathrm{C}$ experiments. In these latter experiments, larger zooplankton are removed by pre-screening the sample before incubation. The heterotrophic nanoplankton, however, are not eliminated. The result, therefore, is that the production of picoplankton may be underestimated, whereas net plankton production is enhanced. An example of this result was observed by Prézelin et al. (1986), and is also illustrated by the data shown in Table 2. At the coastal station, P1, where significant grazing occurred, Synechococcus production estimates from the dilution and frequency of dividing cells technique were an order of magnitude greater than the estimate from the standard dawn-to-dusk ${ }^{14} \mathrm{C}$ production experiment (Glover et al. 1986).

Accurate estimates of grazing rates on cyanobacteria are important to the understanding of the dynamics of the open ocean food chain. If, as suggested by Landry et al. (1984), growth coefficients greatly exceed mortality due to grazing, then it would seem that grazing pressure by heterotrophic flagellates and ciliates on cyanobacteria is not severe. Synechococcus biomass may be grazed upon by other organisms or may be transported via fecal pellets to the mesopelagic zone or benthos. If so, the Synechococcus biomass is not recy- 
cled completely within the pelagic food web. Based on our data from the WCE and LIS experiments this may be the case. On the other hand, where $\mathrm{k}$ and $\mathrm{g}$ population coefficients are approximately equivalent, as observed in the data from the Northwest Atlantic neritic station in this preliminary study, the biomass is rapidly recycled and Synechococcus spp. are an important trophic link in the pelagic food web.

Acknowledgements. We thank Drs. H. E. Glover and B. B. Prézelin for allowing L.C. to participate on the R/V Cape Hatteras cruise, and we acknowledge the helpful comments of M. R. Lewis and an anonymous reviewer. This study was funded by NSF grant \#OCE8214764 to E.J.C.

\section{LITERATURE CITED}

Azam, F., Fenchel, T., Field, J. G., Meyer-Reil, L. A., Thingstad, F. (1983). The ecological role of water-column microbes in the sea. Mar. Ecol. Prog. Ser. 10: 257-263

Bienfang, P. K., Takahashi, M. (1983). Ultraplankton growth rates in a subtropical ecosystem. Mar. Biol. 76: 213-218

Campbell, L., Carpenter, E. J. (1986). Diel patterns of cell division in marine Synechococcus spp. (Cyanobacteria): use of the frequency of dividing cells technique to measure growth rate. Mar. Ecol. Prog. Ser. 32: 139-148

Caron, D. A., Davis, P. G., Madin, L. P., Sieburth, J. McN. (1982). Heterotrophic bacteria and bacterivorous protozoa in oceanic macroaggregates. Science 218: 795-797

Cuhel, R., Waterbury, J. B. (1984). Biochemical composition and short term nutrient incorporation patterns in a unicellular marine cyanobacterium, Synechococcus (WH7803). Limnol. Oceanogr. 29: 370-374

Fenchel, T. (1982). Ecology of heterotrophic microflagellates. IV. Quantitative occurrence and importance as bacterial consumers. Mar. Ecol. Prog. Ser. 9: 35-42

Fenchel, $T$ (1984). Suspended marine bacteria as a food source. In: Fasham, M. J. R. (ed.) Flows of energy and materials in marine ecosystems. Plenum Publ. Corp., New York, p. 301-316

Fuhrman, J. A., Bell, T. M. (1985). Biological considerations in the measurement of dissolved free amino acids in sea water and implications for chemical and microbiological studies. Mar. Ecol. Prog. Ser. 25: 13-21

Fuhrman, J. A., McManus, G. B. (1984). Do bacteria-sized marine eukaryotes consume significant bacterial production? Science 224: 1257-1260

Glover, H. E., Campbell, L., Prézelin, B. B. (1986). Contribution of Synechococcus spp. to size-fractioned primary productivity in three water masses in the Northwest Atlantic. Mar. Biol. 91: 193-203

Goldman, J. C., Mc Carthy, J. J., Peavey, D. G. (1979). Growth rate influence on the chemical composition of phytoplankton in oceanic waters. Nature, Lond. 279: 210-215

Harbison, G. R., McAllister, V. L. (1979). The filter-feeding rates and particle retention efficiency of three species of Cyclosalpa (Tunicata, Thaliacea). Limnol. Oceanogr. 24: $875-892$

Iturriaga, R., Mitchell, B. G. (1986). Chroococcoid cyanobacteria: a significant component in the food web dynamics of the open ocean. Mar Ecol. Prog. Ser. 28: 291-297

Johnson, P. W., Xu, H., Sieburth, J. McN. (1982). The utilization of chroococcoid cyanobacteria by protozooplankters but not by calanoid copepods. Ann. Inst. océanogr., Paris 58(S): $297-308$

King, K. R., Hollibaugh, J. T., Azam, F. (1980). Predator-prey interactions between the larvacean Oikopleura dioica and bacterioplankton in enclosed water columns. Mar. Biol. 56: 49-57

Kopylov, A. V., Moiseev, E. S. (1980). Effect of colorless flagellates on the determination of bacterial production in sea water. Dokl. Akad. Nauk. SSSR Biol. Sci. 252: 272-274

Landry, M. R., Hassett, R. P. (1982). Estimating the grazing impact of marine micro-zooplankton. Mar. Biol. 67: 283-288

Landry, M. R., Haas, L. W., Fagerness, V. L. (1984). Dynamics of microbial plankton communities: experiments in Kaneohe Bay, Hawaii. Mar. Ecol. Prog. Ser. 16: 127-133

Li, W. K. W., Subba Rao, D. V., Harrison, W. G., Smith, J. C. Cullen, J. J., Irwin, B., Platt, T. (1983). Autotrophic picoplankton in the tropical ocean. Science $219: 292-295$

Malone, T. C. (1971). The relative importance of nanoplankton and netplankton as primary producers in tropical oceanic and neritic phytoplankton communities. Limnol. Oceanogr. 16: 633-639

Mullin, M. M. (1983). In situ measurement of filtering rates of the salp, Thalia democratica, on phytoplankton and bacteria. J. Plankton Res. 5: 279-287

Newell, S. Y., Sherr, B. F., Sherr, E. B., Fallon, R. D. (1983). Bacterial response to the presence of eukaryotic inhibitors in water from a coastal marine environment. Mar. Environ. Res. 10: 147-157

Perkins, F. O., Haas, L. W., Phillips, D. E., Webb, K. L. (1981). Ultrastructure of a marine Synechococcus possessing spinae. Can. J. Microbiol. 27: 318-329

Platt, T., Subba Rao, D. V., Irwin, B. (1983). Photosynthesis of picoplankton in the oligotrophic ocean. Nature, Lond. 301 : $702-704$

Pomeroy, L. R. (1974). The ocean's food web: a changing paradigm. Bioscience 24: 499-503

Prézelin, B. B., Putt, M., Glover, H. E. (1986). Diumal patterns in photosynthetic capacity and depth-dependent photosynthesis-irradiance relationships in Synechococcus spp. and larger phytoplankters in three water masses in the Northwest Atlantic. Mar. Biol. 91: 205-217

Repak, A. J. (1983). Suitability of selected marine algae for growing the marine heterotrich ciliate Fabrea salina. J. Protozool. 30 (1): 52-54

Sherr, B. F., Sherr, E. B. (1983). Enumeration of heterotrophic microprotozoa by epifluorescence microscopy. Estuar. coast. Shelf Sci. 16: 1-7

Sherr, B. F., Sherr, E. B., Andrew, T. L., Fallon, R. D., Newell, S. Y (1986). Trophic interactions between heterotrophic Protozoa and bacterioplankton in estuarine water analyzed with selective metabolic inhibitors. Mar. Ecol. Prog. Ser. 32: 169-180

Sieburth, J. McN. (1984). Protozoan bactivory in pelagic marine waters. In: Hobbie, J. E., Williams, P. J. leB. (ed.) Heterotrophic activity in the sea. NATO Conference Series IV, Vol. 15 Plenum Publ. Corp., New York, p. 405-444

Sieburth, J. McN., Davis, P. G. (1982). The role of heterotrophic nanoplankton in the grazing and nuturing of planktonic bacteria in the Sargasso and Caribbean Seas. Ann. Inst. océanogr., Paris. 58 (S): 285-296

Silver, M. W., Alldredge, A. L. (1981). Bathypelagic marine snow: deep-sea algal and detrital community. J. mar. Res. 39: $501-530$

Sokal, R. R., Rohlf, F. J. (1969). Biometry. W. H. Freeman and Co., San Francisco 
Takahashi, M., Bienfang, P. K. (1983). Size structure of phytoplankton biomass and photosynthesis in subtropical Hawaiian waters. Mar. Biol. 76: 203-211

Takahashi, M., Hori, T. (1984). Abundance of picophytoplankton in the subsurface chlorophyll maximum layer in subtropical and tropical waters. Mar Biol. 79: 177-186

Watanabe, Y (1972). Inhibitors of animal virus relication. In: Hochester, R. M., Kates, M., Quastel, J. H. (ed.) Metabolic inhibitors: a comprehensive treatise. Vol. 3, Chap. 8. Academic Press, New York, p. 258-259

Waterbury, J. B. (1984). In situ diel rhythms of marine Synechococcus. EOS (Trans. Am. Geophys. Un.) 65 (45): 896

Williams, P. J. leB. (1981). Incorporation of microheterotrophic processes into the classical paradigm of the planktonic food web. Kieler Meeresforsch. (Sonderh.) 5: 1-28

This article was presented by Dr. M. R. Lewis; it was accepted for printing on August 14,1986 